\title{
Addressing Challenges of Urban Water Management in Chinese Sponge Cities via Nature-Based Solutions
}

\author{
Yunfei Qi ${ }^{1,2, *}$, Faith Ka Shun Chan ${ }^{1,3,4, *} \mathbb{0}$, Colin Thorne ${ }^{5, *}$, Emily O'Donnell $^{5}$, \\ Carlotta Quagliolo ${ }^{6}\left({ }^{\circ}\right.$, Elena Comino ${ }^{7}$, Alessandro Pezzoli ${ }^{6}$, Lei Li ${ }^{1}$, James Griffiths ${ }^{8}$, \\ Yanfang Sang ${ }^{9}$ and Meili Feng ${ }^{1}$ \\ 1 School of Geographical Sciences, University of Nottingham Ningbo, Ningbo 315100, China; \\ zy13104@nottingham.edu.cn (L.L.); meili.feng@nottingham.edu.cn (M.F.) \\ 2 Guizhou Survey \& Design Research Institute for Water Resources and Hydropower, Guiyang 550002, China \\ 3 School of Geography, University of Leeds, Leeds LS2 9JT, UK \\ $4 \quad$ Water@Leeds Research Institute, University of Leeds, Leeds LS2 9JT, UK \\ 5 School of Geography, University of Nottingham, Nottingham NG7 2RD, UK; \\ emily.o'donnell@nottingham.ac.uk \\ 6 DIST-Interuniversity Department of Regional and Urban Studies and Planning, Politecnico di Torino and \\ Università degli Studi di Torino, 10125 Torino, Italy; carlotta.quagliolo@polito.it (C.Q.); \\ alessandro.pezzoli@polito.it (A.P.) \\ 7 DIATI-Department of Environment, Land and Infrastructure Engineering, Politecnico di Torino, \\ 10129 Torino, Italy; elena.comino@polito.it \\ 8 National Institute of Water \& Atmospheric Research Ltd (NIWA), Christchurch 8602, New Zealand; \\ James.Griffiths@niwa.co.nz \\ 9 Institute of Geographic Sciences and Natural Resources Research Chinese Academy of Sciences: Beijing, \\ Beijing 100000, China; sangyf@igsnrr.ac.cn \\ * Correspondence: yunfei.qi@nottingham.edu.cn (Y.Q.); faith.chan@nottingham.edu.cn (F.K.S.C.); \\ Colin.Thorne@nottingham.ac.uk (C.T.); Tel.: +86-0851-85584746 (Y.Q.); +86-0574-88180000 (F.K.S.C.); \\ +44-0115-95-15431 (C.T.)
}

Received: 2 September 2020; Accepted: 5 October 2020; Published: 8 October 2020

\begin{abstract}
Urban flooding has become a serious issue in most Chinese cities due to rapid urbanization and extreme weather, as evidenced by severe events in Beijing (2012), Ningbo (2013), Guangzhou (2015), Wuhan (2016), Shenzhen (2019), and Chongqing (2020). The Chinese "Sponge City Program" (SCP), initiated in 2013 and adopted by 30 pilot cities, is developing solutions to manage urban flood risk, purify stormwater, and provide water storage opportunities for future usage. Emerging challenges to the continued implementation of Sponge Cities include (1) uncertainty regarding future hydrological conditions related to climate change projections, which complicates urban planning and designing infrastructure that will be fit for purpose over its intended operating life, and (2) the competing priorities of stakeholders and their reluctance to make trade-offs, which obstruct future investment in the SCP. Nature-Based Solutions (NBS) is an umbrella concept that emerged from Europe, which encourages the holistic idea of considering wider options that combine "Blue-Green" practices with traditional engineering to deliver "integrated systems of Blue-Green-Grey infrastructure". NBS includes interventions making use of natural processes and ecosystem services for functional purposes, and this could help to improve current pilot SCP practices. This manuscript reviews the development of the SCP, focusing on its construction and design aspects, and discusses how approaches using NBS could be included in the SCP to tackle not only urban water challenges but also a wide range of social and environmental challenges, including human health, pollution (via nutrients, metals, sediments, plastics, etc.), flood risk, and biodiversity.
\end{abstract}


Keywords: Sponge City Program (SCP); Nature-Based Solutions (NBS); urban water; flood risk management; blue-green infrastructure; multiple co-benefits

\section{Introduction}

Urban water management issues, such as water scarcity, surface water flooding, and freshwater pollution, are occurring more frequently worldwide [1]. Governments, especially in "More Economically Developed Countries" (MEDCs), have realized the urgency of solving these urban water problems and integrating solutions with new urban water management strategies and practices based on the concepts of "Sustainable Development", "Biodiversity", "Natural Capital", "Ecosystem Services", or "Ecosystem-based approaches", and, lately, "Nature-Based Solutions" (NBS). Many cities are now implementing these practices [2]. NBS are defined as interventions inspired and supported by nature, which are cost-effective while delivering a range of environmental, social, and economic benefits $[3,4]$. Indeed, these solutions can address multiple urban challenges related to environmental dimensions including not only climate change adaptation and water management but also economic and social dimensions such as green economics, human well-being, social equity, and public health $[5,6]$. Conceptually, NBS aims to bring nature in general, and natural features and processes in particular, into cities, landscapes, and seascapes. In the context of cities, NBS often acts as an "umbrella" concept in improving urban sustainability [4,7]. NBS is particularly useful for improving urban water issues by aligning water management strategies with existing urban planning, design, and implementation in new development and renovation projects.

Urban water challenges, particularly flooding, have frequently impacted Chinese cities in recent years, owing to the rapid urbanization, land-use changes, and inadequate design standards for drainage systems (i.e., 1-in-5 year return period) [8]. The Chinese government had primarily focused on strengthening engineered water infrastructure (e.g., river channelization, dams, and reservoirs; levees; embankments; floodwalls) to reduce urban flood risk [9]. Since the standards of living in China have improved, citizens are now seeking better quality and safer urban environments. This has shifted current urban water management in Chinese cities in greener and sustainable directions [10]. In 2013, the Chinese National Government formally proposed the "Sponge City Program" (SCP), which addresses urban stormwater problems (e.g., urban floods and pollution) by using more ecologically friendly approaches that have tested in 30 pilot cities across the country for various climatic, hydrological, and geographical patterns [9]. However, as the SCP has only been implemented for a few years and lacks holistic monitoring, it is too early to establish its effectiveness and performance [11].

Recognizing this, the aim of this paper is to critically review the practices and management strategies of NBS and review recent concepts, measures, and developments of similar global practices for urban water management that have influenced the Chinese SCP (Section 2). Current challenges and barriers to the effective delivery of the SCP are discussed in Section 3. Next, we investigate the potential challenges that will influence the SCP implementation in the Chinese context (Section 4). Finally, we examine recent progress in implementing NBS to explore how that concept may further improve the SCP in China with respect to tackling challenges relating to current urban issues (Section 5).

In fact, all the authors in this review fully understand that there are differences in governance (e.g., in urban planning practices and processes and the urban water management context) between China and elsewhere; thus, the SCP cannot be overly reliant on global practices and experience, which may not be transferrable to Chinese contexts. Still, lessons learned from other global cities could help improve the implementation of SCP. 


\section{NBS and Urban Water Management}

\subsection{Development and Concept of NBS}

During the last two decades, concepts such as "Sustainable Development", "Biodiversity", and "Ecosystem Services" focused primarily on what nature can provide to humans, which is an anthropocentric notion [12]. Global societies are seeking to address challenges relating to health, food security, and water and energy sustainability, while aiming to reconnect the urban environment with nature. There are many examples that demonstrate a shift with respect to nature in urban planning and water management policies, such as "Making Space for Water" in the United Kingdom (established in 2004) [13] and "Room for the River" in the Netherlands (established in the late 1990s) [14]—and also, more recently, creating more "Blue-Green" spaces to generate multiple co-benefits, improve biodiversity, and increase climate change resilience in cities [15]. On the same spectrum, NBS appeared as a concept at the beginning of the 21st century and supported the proactive management of nature with the goal of enhancing urban ecosystem services and benefits from them [16]. Evidently, NBS seeks to combine and build on earlier approaches as they have been defined in the literature [5]. For example, the International Union for Nature Conservation (IUCN) has recently defined NBS as "actions to protect, sustainably manage and restore natural or modified ecosystems in ways that address societal challenges efficiently and adaptively to provide both human well-being and biodiversity benefits" [17]. This definition focuses on nature, rather than the practical utility of nature, while stressing how becoming closer to nature can help communities deal with social challenges and adaptation to a changing environment. Conversely, although the European Commission (EC) have defined the concept similarly, they focus more on the social and political aspects of NBS, emphasizing how it can contemporaneously provide social, economic, and environmental benefits through local-adaptive interventions, such as restoring urban ecosystems, and improving urban resilience and sustainability [18]. The goals of NBS stated by the EC include essentially sustainable urbanization, the restoration of degraded ecosystems, climate change adaptation and mitigation, resilience, and risk management [19]. Therefore, this definition appears more related to a society's market orientation and economy. The definitions of NBS are thus varied and highly dependent on context [20].

European Commission programmes (e.g., Horizon 2020-the EU Framework Programme for Research and Innovation) seek to promote emergent, common goals across projects, while recognizing that, in practice, each project must provide different solutions to different problems. NBS demonstration projects are designed to build evidence and an NBS knowledge base, particularly through the co-design and co-implementation of solutions. Hence, despite the wide range of definitions, one of the major strengths of NBS lies in its capacity to integrate the societal domain by linking ecosystem services, social concerns, and governance both conceptually and practically [21].

We understand NBS to embrace the use of proactive environmental management and the enhancement of natural features and processes to better balance the urban water cycle, thereby enhancing water quality, water security, and flood risk management [22]. Conventionally, the urban water cycle differs from the natural water cycle with regards to its main components: interception, evapotranspiration, runoff, infiltration, and groundwater storage. These differences have adverse consequences for the urban climate, ground water recharge, and water-related risk management. In essence, NBS aims to mitigate these effects by re-establishing a more natural water cycle. For example, in 2014, the EU developed "Natural Water Retention Measures" (NWRM), which promote the use of Green Infrastructure in the water sector. These NBS assets are multi-functional, being intended to both protect water resources and address water-related challenges by restoring or conserving ecosystems, while capturing the multiple co-benefits envisaged for Blue-Green infrastructure (http://nwrm.eu/).

\subsection{International Urban Water Management Progress}

The concept of NBS is a systematic ecological theory summarized from practices [23]. Prior to the emergence of NBS, many countries had already developed pioneering ecological programmes. In the 
1970s, "Best Management Practices" (BMPs), which include nature-based approaches, were introduced in North America to control urban stormwater pollution. BMPs can be structural (i.e., sediment control fences to retain sediment on a construction site) or non-structural (i.e., monitoring to ensure sediment concentrations downstream of construction sites stay below a permitted level) [24]. In the US, the adoption of BMPs is regulated by the Environmental Protection Agency (EPA), which has developed a BMPs Siting Tool to guide urban planners, architects, and developers [25]. In the UK, "Sustainable Drainage Systems" (SuDs) define a range of techniques used to store, infiltrate, and drain surface water, in order to manage flood risk while delivering co-benefits of water quality, biodiversity, and amenity [26]. Since the 1990s, SuDs have becoming increasingly widespread in the UK [27]. In the early 1990s, "Low Impact Development" (LID) was developed in North America and New Zealand [28] as a principle for guiding sustainable urban planning and building design to better simulate the natural water cycle [29].

"Water Sensitive Urban Design" (WSUD) originated in the 1990s from Australia, aiming to protect the natural environment and improve citizens' quality of life [30]. WSUD is the cornerstone of many urban planning and urban water management principles [31], and global cities such as Melbourne and Sydney have adopted WSUD in master planning since the 1990s [32]. Across the Tasman Sea, New Zealand developed "Low Impact Urban Design and Development" (LIUDD) by merging LID and WSUD [33]. This focuses on the comprehensive consideration of water quantity and quality, biodiversity, and land use in urban development. While WSUD and SuDs centre on urban planning and infrastructure, urban development is a social-cultural issue, and so it is also important to implement cultural integration in order for these concepts to transition smoothly into the local communities and practices. Recognizing this, the Government of New Zealand placed stakeholder dialogue and inclusion among multiple, diverse communities, ethnicities, and cultures at the core of its LIUDD approach [34]. Attention to issues of cultural integration is lacking in several more physically centric approaches to urban water management, including the current SCP.

In the early 2000s, via the further integration of BMP techniques and LID principles, "Green Infrastructure" (GI) was implemented across the Western hemisphere to manage stormwater and improve environmental, social, and economic sustainability [35]. Similar concepts have influenced Asia-Pacific cities, such as the "Active Beautiful and Clean Waters" (ABC) programme initiated in Singapore in the mid-2000s, which aims to promote more active, beautiful, and clean-living environments for the public using "Blue-Green Infrastructure" (BGI) measures [36]. In the early 2010s, several UK cities stated the aspiration to become a "Blue-Green City" (BGC) [37], which is a city that aims to recreate a more naturally oriented water cycle in its urban environment by merging its management of the urban water cycle with its management of public green spaces and corridors [38]. Knowledge gained about urban planning and urban water management through these practices creates a solid foundation for the adoption of NBS within the SCP.

\subsection{Urban Water Management Policies in Chinese Cities}

Since the Chinese National Government established its reform and opening-up policy in 1979, many cities have developed rapidly, especially along the coast [39]. In the 1980s, urban populations only accounted for $19 \%$ of the population, but by 2015 , this had increased to $60 \%$ [40]. Rapid urbanization has led to multiple urban water issues, including water shortages and pollution, increased urban flooding, and the deterioration of urban water quality [41]. Since the millennium, over $60 \%$ of Chinese cities have suffered water shortages, including 30 out of the 32 Chinese megacities [42]. In the 2018 National State of the Environment Report, more than $74 \%$ of cities were identified as having a poor groundwater quality status [43]. Currently, urban drainage standards are mostly 1-in-1 to 1-in-5 year return period storms, which is insufficient to cope with rising urban flood risk [44]. In July 2020 alone, more than 20 million people were affected by floods, across many cities in 24 Provinces [45].

The first turning point in China was in 2002, when a societal water-saving construction policy was set by central government [46]. There was further progress between 2003 and 2007, as megacities 
including Beijing began to better manage stormwater by improving their urban drainage systems and water pollution treatment works [47]. Between 2008 and 2010, water resource-optimization strategies were invoked to optimize the spatial redistribution of water resources [48]. In 2012, the city of Shenzhen began experimentally implementing LID [49]. Traditionally, Chinese water resource management policy was to rely solely on engineering measures (i.e., dams, canals, and water transfers) to manage water resources. For example, since the 1950s, over 97,000 reservoirs have been constructed for the purposes of enhancing the potable water supply, irrigation, hydro-electric power generation, and flood control. These dams are primarily located upstream of urban conurbations [50]. These traditional approaches have been effective in reducing inundation frequencies in cities located along streams and rivers (flash and fluvial floods) lower in the catchment, although urban growth means that the damage generated when a flash or fluvial flood does occur have increased. Furthermore, pluvial and surface water flooding remains an issue in Chinese cities due to substantial reductions in urban greenspaces [51].

According to a survey of 351 Chinese cities conducted by the Ministry of Housing and Urban-Rural Development (MHURD), more than 62\% suffered urban flooding between 2008 and 2010 [52], and in 2012 and 2013, urban floods were documented in 184 and 234 cities, respectively [53], including severe events such as the Beijing flood on 21 July 2012, which caused widespread disruption and 79 deaths [54]. The frequency, geographical spread, and severity of these urban shortage and flood events convinced central government that historical and current urban flood prevention strategies were insufficient, prompting the move towards novel and innovative solutions to urban flood and water management (Figure 1).

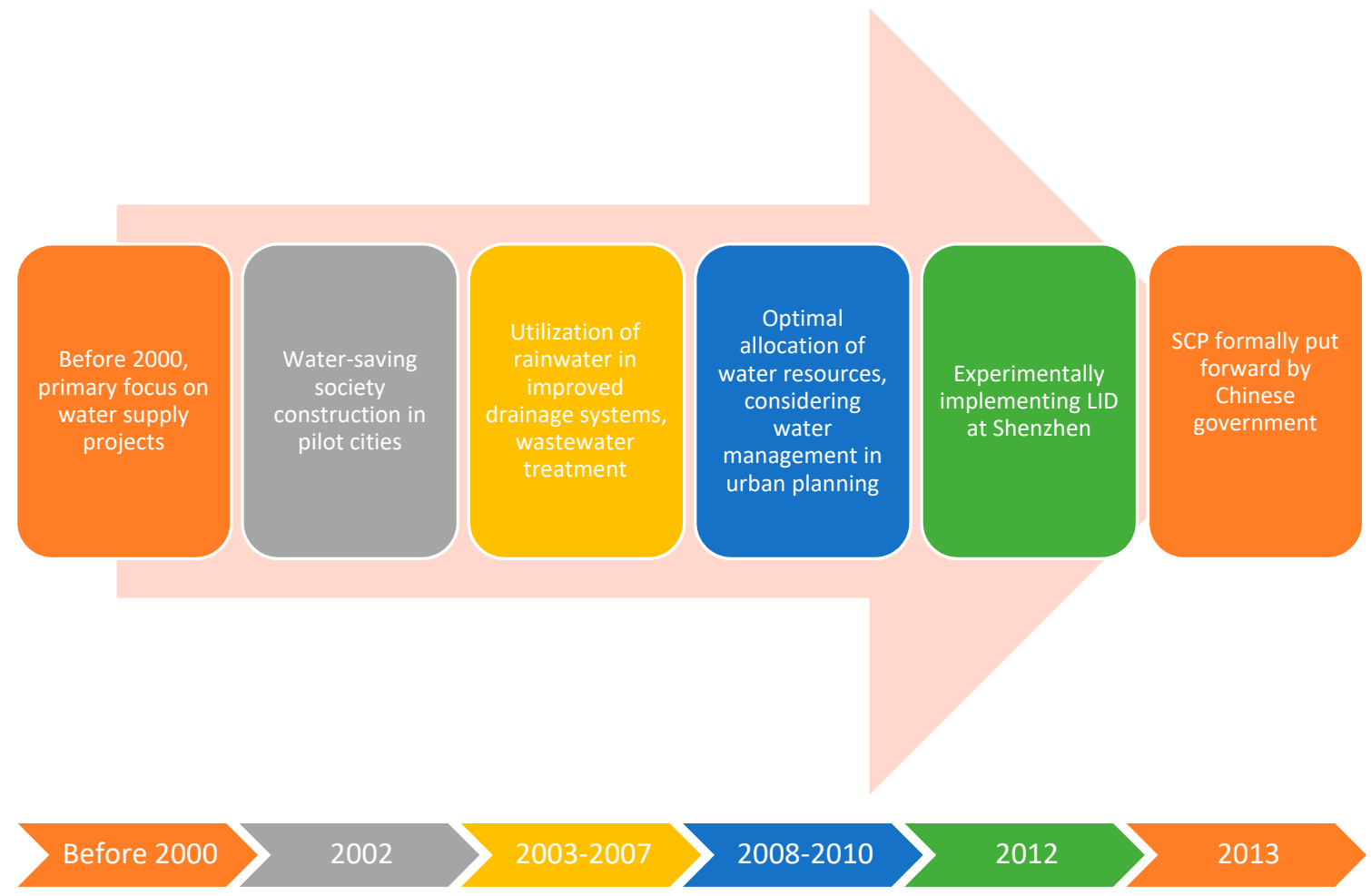

Figure 1. The urban water management policies in China from before 2000 to present. Source: authors.

\subsection{The Principle, Initiation, and Development of the SCP}

The "Sponge City Program" (SCP) was formally proposed in 2013 as a new sustainable urban developing strategy [55]. The core concept is not actually new; it originates from ancient Chinese "Water Town" practices. For example, in Ningbo and Suzhou, Chinese farmers traditionally used farmland as flood buffer zones for urban areas [56]. The "Sponge City Program", which is a practice 
that describes using the concept of a sponge to absorb water during the storms and release water after soil-water processing (infiltration and purification) back to the urban runoff, operating like a sponge (Figure 2) [57].

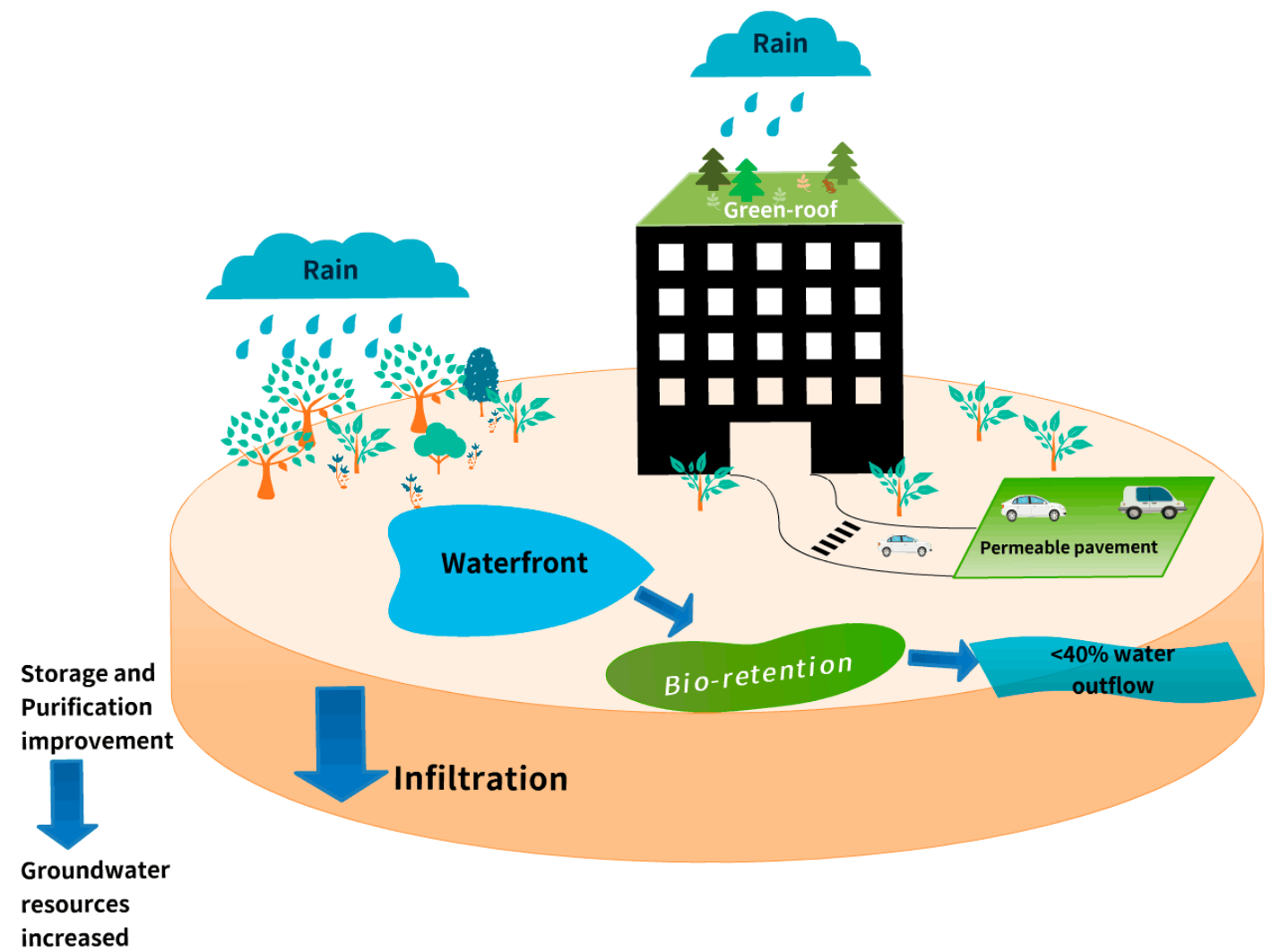

Figure 2. Sponge City Program (SCP) principle and concept [9]. Drawn by the authors.

The SCP aims to restore the urban hydro-system using eco-friendly measures (i.e., Green or Blue-Green/Grey policies and integrated infrastructure systems) that collect, manage, and reuse urban water [58]. Table 1 chronicles the development of SCP. By the end of 2016, 30 cities-Wuhan, Chongqing, Xiamen, Beijing, Tianjin, Dalian, Shanghai, Ningbo, Shenzhen, Sanya, and Gui'an New District-had been selected as pilot Sponge Cities according to the various climatic (precipitation patterns-South, East, Mid-West, North, and North-East), topographic (e.g., mountainous, coastal, lowland, etc.), and socio-economic conditions (e.g., selection from population sizes across megacities with 10 million or more, large cities (with 6-8 million), medium cities (with 3-5 million), and small cities (with 1-2 million)) [59].

Table 1. The development process of the SCP in China.

\begin{tabular}{|c|c|c|}
\hline Timeline & Stage of Chinese Water Management & Citations \\
\hline 2013 & SCP was formally put forward by Chinese central government & [8] \\
\hline 2014 & Technical Guidelines for Sponge City Construction (trial) were released & [60] \\
\hline 2015 & $\begin{array}{l}\text { The first batch of } 16 \text { pilot sponge cities was selected. The performance } \\
\text { evaluation and examination of methods for this trial construction was } \\
\text { published. "Guiding Opinions" was issued }\end{array}$ & [51] \\
\hline 2016 & The second batch of 14 pilot sponge cities was selected & [61] \\
\hline 2016 & The total 30 pilot sponge cities started to prepare Sponge City Urban Planning & [52] \\
\hline 2018 & $\begin{array}{l}\text { The Ministry of Housing and Urban-Rural Development (MHURD) } \\
\text { published the first draft of SCP assessment standards }\end{array}$ & [62] \\
\hline
\end{tabular}


The National Government has initiated short-, medium-, and long-term development targets to deliver SCP as follows:

1. Short term (from 2015 to 2018), which promote the SCP in the 30 selected pilot cities, and demonstrate and establish the small-scale plot-sized pilot SCP construction projects (e.g., SCP urban parks, artificial wetlands, urban ponds, etc.);

2. Medium term (from 2018 to 2020), which establish and legislate the performance of SCP (e.g., stormwater discharge and ability for flood reduction, etc.), aiming to expand the SCP infrastructures to $20 \%$ of municipal areas by the end of 2020;

3. Long term (from 2020 to 2030), which implement SCP in urban development and planning strategies (e.g., urban master plans), aiming at more than $80 \%$ of municipal areas having SCP infrastructures towards the end of the 2030s [59].

Table 2 illustrates the functions and roles of stakeholders in the SCP delivery at the municipal level for all the pilot cities for the SCP delivery. For example, the National Development and Reform Commission is responsible for evaluating and granting approval for SCP project implementations, while the Ministry of Finance manages SCP project investments. The MHURD is responsible for finalizing and publishing the "SCP Guidelines for Planning and Design", as well as supervising SCP project construction. The Ministry of Water Resources focuses on water resource management in SCP pilot cities [8]. Local governments directly manage the individual SCP projects.

Table 2. Major stakeholders and their roles and functions of the SCP in pilot cities [63-65].

\begin{tabular}{|c|c|c|}
\hline Stakeholders & Institution & Roles/Duties \\
\hline Governmental Bureau & $\begin{array}{l}\text { Ministry of Housing and Urban } \\
\text { and Rural Development } \\
\text { (HMURD) }\end{array}$ & $\begin{array}{l}\text { Operates and delivers SCP practices and is } \\
\text { responsible for all SCP construction projects } \\
\text { in the allocated } 30 \text { pilot Chinese cities. }\end{array}$ \\
\hline Governmental Bureau & $\begin{array}{l}\text { Ministry of Water Resources } \\
\text { (MWR) }\end{array}$ & $\begin{array}{c}\text { Responsible for the land drainage system, } \\
\text { offloading stormwater, and urban surface } \\
\text { water management including all pluvial or } \\
\text { inland floods. }\end{array}$ \\
\hline Governmental Bureau & Local Planning Department & $\begin{array}{l}\text { integrate SCP practice into local development } \\
\text { plans for planning processes. }\end{array}$ \\
\hline Governmental Bureau & Land Resources Bureau & $\begin{array}{l}\text { Coordinate land-use management-related } \\
\text { work with the SCP projects and practices. }\end{array}$ \\
\hline Governmental Bureau (cont.) & Ministry of Forestry & $\begin{array}{l}\text { Manage vegetation, green spaces, and } \\
\text { maintenance of flora in the SCP practice. }\end{array}$ \\
\hline Communities & $\begin{array}{l}\text { Non-Governmental Organizations } \\
\text { (NGOs) and Community groups }\end{array}$ & $\begin{array}{l}\text { Present the public views and opinions of } \\
\text { residents living by the SCP infrastructure } \\
\text { (SCP Parks) to the Governmental bureaus and } \\
\text { enhance participation. }\end{array}$ \\
\hline \multirow[t]{2}{*}{ Private sectors } & Developers & $\begin{array}{l}\text { To develop the surrounding areas that } \\
\text { affiliate with the SCP infrastructure and } \\
\text { engage with the municipal governments to } \\
\text { enhance Public-Private-Partnerships (PPPs). }\end{array}$ \\
\hline & Banks and Insurers & $\begin{array}{l}\text { To provide financial support and insurance } \\
\text { for the SCP projects. }\end{array}$ \\
\hline
\end{tabular}

Figure 3 illustrates the management system for the implementation of SCP projects. SCP implementation has four stages:

1. Planning;

2. Design;

3. Construction;

4. Maintenance. 


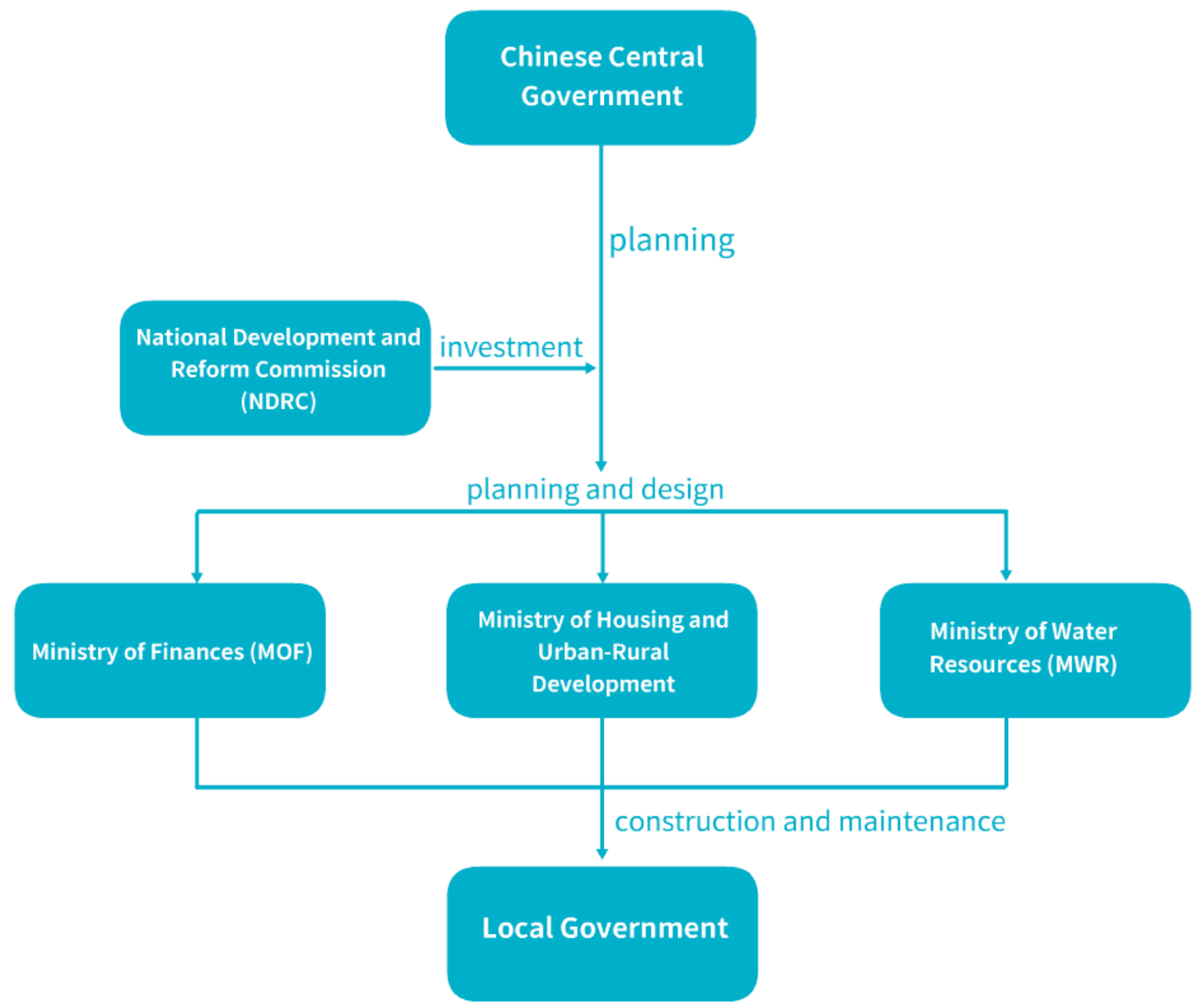

Figure 3. The roles of governmental institutions in SCP practice. Source: authors.

Each stage is evaluated using the MUHRD-SCP Guidelines (Table 3) to ensure that the projects in the pilot are completed for target Sponge Cities. 
Table 3. SCP technical measures [8-10,40,53,66-68].

\begin{tabular}{|c|c|c|c|c|c|c|c|c|c|c|c|c|c|c|}
\hline \multirow[b]{2}{*}{ Facilities } & \multicolumn{5}{|c|}{ Function } & \multicolumn{3}{|c|}{ Control Objectives } & \multicolumn{2}{|c|}{$\begin{array}{l}\text { Disposal } \\
\text { Method }\end{array}$} & \multicolumn{2}{|c|}{ Cost } & \multirow[b]{2}{*}{$\begin{array}{l}\text { Suspended Solid } \\
\text { Removal Rate for } \\
\text { Pollutants (\%) }\end{array}$} & \multirow[b]{2}{*}{$\begin{array}{c}\text { Landscape } \\
\text { Effect }\end{array}$} \\
\hline &  & 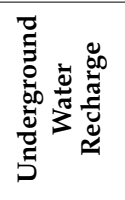 & 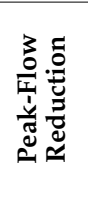 & 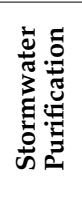 & 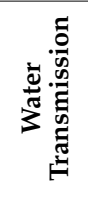 & 劳泀 & 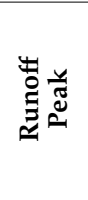 & 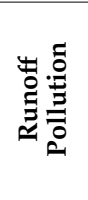 & 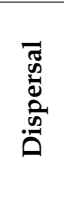 & 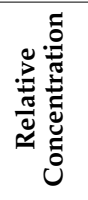 & 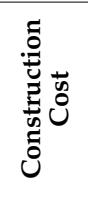 & 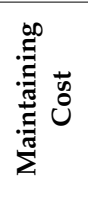 & & \\
\hline Permeable pavement & $\nabla$ & $\bullet$ & $\square$ & $\square$ & $\square$ & $\bullet$ & $\square$ & $\square$ & $\sqrt{ }$ & - & Low & Low & $80-90$ & - \\
\hline Permeable cement & $\nabla$ & $\nabla$ & $\square$ & 口 & $\square$ & $\square$ & 口 & 口 & $\sqrt{ }$ & - & High & Mid & $80-90$ & - \\
\hline Permeable asphalt & $\nabla$ & $\nabla$ & $\square$ & $\square$ & $\square$ & 口 & $\square$ & $\square$ & $\sqrt{ }$ & - & High & Mid & $80-90$ & - \\
\hline Green roof & $\nabla$ & $\nabla$ & $\square$ & 口 & $\square$ & - & $\square$ & $\square$ & $\sqrt{ }$ & - & High & Mid & $70-80$ & Great \\
\hline Sunken green space & $\nabla$ & - & $\square$ & 口 & $\square$ & - & $\square$ & $\square$ & $\sqrt{ }$ & - & Low & Low & - & Fair \\
\hline Simple bio-detention & $\nabla$ & - & $\square$ & $\square$ & $\square$ & - & $\square$ & $\square$ & $\sqrt{ }$ & - & Low & Low & - & Great \\
\hline Integrated bio-detention & $\nabla$ & - & $\square$ & - & 口 & - & $\square$ & $\bullet$ & $\sqrt{ }$ & - & Mid & Low & $70-95$ & Great \\
\hline Permeable pond & $\nabla$ & - & $\square$ & $\square$ & $\square$ & - & $\square$ & $\square$ & - & $\sqrt{ }$ & Mid & Mid & $70-80$ & Fair \\
\hline Seepage well & $\nabla$ & - & $\square$ & 口 & $\square$ & - & $\square$ & 口 & $\sqrt{ }$ & $\sqrt{ }$ & Low & Low & - & - \\
\hline Wet pond & - & $\nabla$ & - & $\square$ & 口 & - & - & $\square$ & - & $\sqrt{ }$ & High & Mid & $50-80$ & Great \\
\hline Rainwater wetland & - & $\nabla$ & - & - & 口 & - & - & - & $\sqrt{ }$ & $\sqrt{ }$ & High & Mid & $50-80$ & Great \\
\hline Impounding pool & - & $\nabla$ & 口 & $\square$ & $\square$ & - & $\square$ & $\square$ & - & $\sqrt{ }$ & High & Mid & $80-90$ & - \\
\hline Rainwater tank & - & $\nabla$ & $\square$ & $\square$ & 口 & - & $\square$ & 口 & $\sqrt{ }$ & - & Low & Low & $80-90$ & - \\
\hline Regulating pond & $\nabla$ & $\nabla$ & - & 口 & 口 & $\nabla$ & - & 口 & - & $\sqrt{ }$ & High & Mid & - & Fair \\
\hline Regulating pool & $\nabla$ & $\nabla$ & - & $\nabla$ & 口 & $\nabla$ & - & $\nabla$ & - & $\sqrt{ }$ & High & Mid & - & - \\
\hline Transfer-type grass ditch & 口 & $\nabla$ & $\nabla$ & $\square$ & - & $\square$ & $\nabla$ & 口 & $\sqrt{ }$ & - & Low & Low & $35-90$ & Fair \\
\hline Dry grass ditch & $\nabla$ & $\nabla$ & $\nabla$ & $\square$ & - & - & $\nabla$ & $\square$ & $\sqrt{ }$ & - & Low & Low & $35-90$ & Great \\
\hline Wet grass ditch & $\nabla$ & $\nabla$ & $\nabla$ & - & - & $\nabla$ & $\nabla$ & • & $\sqrt{ }$ & - & Mid & Low & - & Great \\
\hline Permeable tube/canal & $\nabla$ & 口 & $\nabla$ & $\nabla$ & - & 口 & $\nabla$ & 口 & $\sqrt{ }$ & - & Mid & Mid & $35-70$ & - \\
\hline Vegetation buffer zone & $\nabla$ & $\nabla$ & $\nabla$ & $\bullet$ & - & $\nabla$ & $\nabla$ & $\bullet$ & $\sqrt{ }$ & - & Low & Low & $50-75$ & Fair \\
\hline $\begin{array}{l}\text { Initial stormwater-abandon } \\
\text { facilities }\end{array}$ & $\square$ & $\nabla$ & $\nabla$ & $\bullet$ & - & $\nabla$ & $\nabla$ & - & $\sqrt{ }$ & - & Low & Mid & $40-60$ & - \\
\hline Artificial infiltrating soil & $\bullet$ & $\nabla$ & $\nabla$ & $\bullet$ & - & $\nabla$ & $\nabla$ & $\square$ & - & $\sqrt{ }$ & High & Mid & $75-95$ & Great \\
\hline
\end{tabular}

Function and Control Objectives: •—High ability; $\square$ —Relative high ability; $\nabla$ —Low ability; Landscape: Great—easily seen; Fair—occasionally seen. 


\subsection{Relationships between NBS, SCP, and Other Relevant Concepts}

NBS aims to deliver positive outcomes for society [69], and in so doing, this umbrella concept embraces several of the older, more focused concepts, principles, and programmes, including BMPs, LID, SuDs, WSUD, LIUDD, Blue-Green Cities (BGCs), and the SCP [70] (Figure 4). For instance, integrating grey infrastructure with natural features and processes to deal with water-related issues in built environments is integral to WSUD and SuDs. NBS goes further though, specifically highlighting the limitations of solutions relying purely on so called "traditional" engineering approaches that actually date only from the late 19th century [23]. The concepts depicted in Figure 4 conform with the NBS concept that encompasses them, in that each aims to provide a range of ecosystem services alongside sustainable structural (i.e., engineered assets) and non-structural (i.e., changes in stakeholder behaviours) measures to deal with urban water issues [71]. It follows that some of the underpinning principles [5] include:

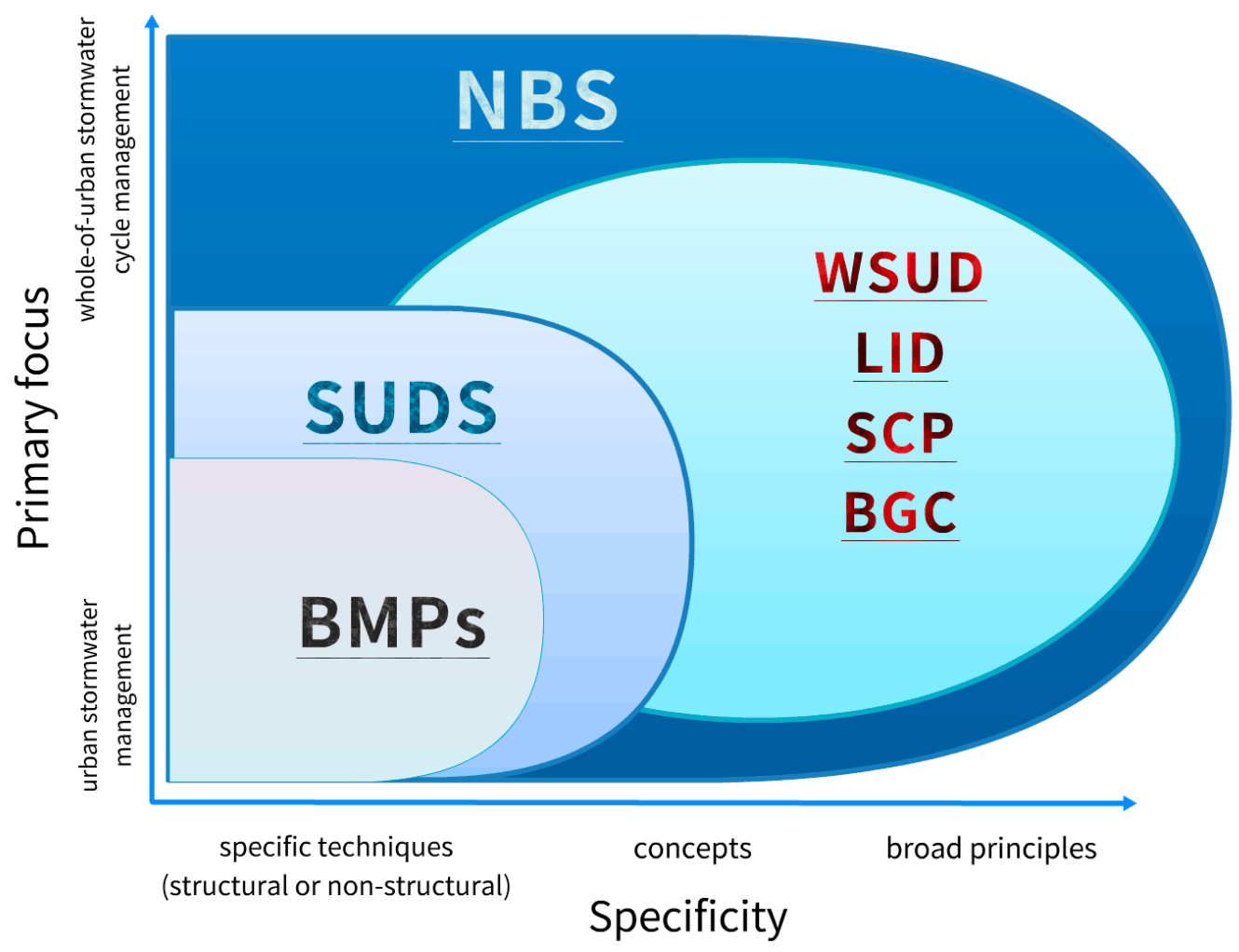

Figure 4. Relationship of Nature-Based Solutions (NBS), Best Management Practices (BMPs), Sustainable Drainage Systems (SuDs), Water Sensitive Urban Design (WSUD), Low Impact Development (LID), Blue-Green Cities (BGCs), and SCP. Source: authors.

1. Recovering or simulating natural hydrological conditions via the protection or restoration of urban ecosystems;

2. Improving water quality;

3. Mitigating urban flood risk;

4. Improving quality of life for residents.

\section{Current Challenges and Barriers to Adopting NBS and Other Innovations in the Chinese SCP}

\subsection{Changing Hydro-Climatic and Geographical Conditions}

Climate change is now bringing more extreme weather worldwide and rendering the assumption of hydroclimatic stationarity untenable. This increases uncertainties in near- and, especially, long-term 
forecasts for the frequency and intensity of both urban floods and droughts [59]. Meanwhile, rapid urbanization is not only changing urban and peri-urban surfaces but also significantly altering urban micro-climates [57]. The SCP pilot cities are located in contrasting geographical areas, with terrains ranging from coastal plains to lowlands and mountains, and regional climates ranging from tropical to temperate forest, which complicates the development of overarching guidance for SCP implementation [72].

\subsection{Urban Flood Risk Management}

Sponge Cities included in the pilot programme (2015-2018) focused on local, site-specific interventions located in residential communities and commercial districts [73]. SCP infrastructure was designed to increase infiltration and increase water retention, to reduce the flood risks associated with precipitation events with short to medium return periods (i.e., $<1$-in-30 years) [74]. However, the early measures lacked holistic consideration of the urban water cycle, focusing only on managing urban stormwater at the plot/site scale and missing opportunities to integrate local measures with the wider hydrological networks in the pilot cities and surrounding areas [60].

Currently, SCP infrastructure designs continue to deal with urban pluvial and surface water runoff during relatively mild rainfall events that would otherwise cause what is commonly referred to as "nuisance flooding". They are not designed to mitigate severe urban surface water floods generated from larger events with longer return periods, such as seasonal "plum rains" and typhoons, which are a serious risk in pilot cities located in southeast China, of which Ningbo, Shenzhen, and Fuzhou are prime examples. Recognizing that climate change is increasing the probability of heavy frontal storms and typhoons, if the SCP is to be effective in reducing urban flood risk and increasing urban flood resilience in these cities, it will be necessary to integrate SCP measures with existing and enhanced engineered assets (e.g., piped drainage systems, dams, and floodwalls) so that they act synergistically to raise flood protection standards in vulnerable urban areas generally, and especially in older districts that lack spaces for large-scale blue-green infrastructure. In this context, the restoration of urban rivers and lakes to increase their capacity to convey, store, and infiltrate urban runoff would efficiently improve the flood risk management capacity of SCP measures, which is a key component of the SCP guidelines [10]. Those guidelines make clear that over-reliance on multiple, distributed, small-scale SCP projects that do not form integrated systems will make achieving the SCP target of a $70 \sim 80 \%$ reduction in total urban runoff by 2030 an uphill struggle [75].

\subsection{Technology and Modelling Capabilities}

Until recently, river flows and surface water runoff were routinely simulated using a runoff-coefficient and a one-dimensional model [75]. However, modelling current and future overland flows in urban contexts is becoming more sophisticated, in order to better represent the variable terrains and surfaces encountered in built environments, and interactions between surface and sub-surface drainage systems, and to account for the impacts of climate and land-use changes. This is essential because in cities, more elements and factors (e.g., rainfall intensity and frequency, variable infiltration, soil moisture conditions and surface roughness, and coincident floods involving pluvial, surface water, groundwater, and river sources) affect the urban water cycle [76]. Water engineers and managers increasingly run two-dimensional hydrologic and hydraulic models (e.g., MIKE-URBAN, MIKE-SWMM, STORM, SWMM, UCURM, ILLUDAS, TRRL, SUSTAIN, MOUSE, and InfoWorks) to simulate complex urban water processes and map potential inundation extents and flood risks [77]. Nonetheless, commercial modelling software needs to be updated and upgraded to simulate the changing urban environments in Chinese cities (e.g., the high intensity of construction and impacts of increasing populations) [78].

Artificial Intelligence (AI) technology is becoming popular in other fields, such as manufacturing, finance, and engineering, and the potential exists for AI optimization technology to be used to improve the understanding of hydrological risk, economic losses, and disaster management in SCP cities $[79,80]$. 
For example, the flood management authorities in India's Patna Region have used Google AI and Google Maps to build a flood forecasting system [81].

\subsection{Finance and SCP Expansion}

Several significant SCP projects have been constructed in Chinese megacities, including the Olympic Park in Beijing and the Guangming New District in Shenzhen. These projects are exemplary SCP projects that are showcased to stakeholders and the public [82]. Historically, only wealthy cities could afford iconic blue-green infrastructure such as wetland parks, due to the high cost of land needed for this type of SCP development [61]. For example, the first round of investment ( 0.3 to 0.5 billion RMB per pilot city) in the SCP was sponsored by the National Government [68], but Municipal Governments are required to finance the latter stages of these projects. Despite the MHURD strongly promoting Public-Private Partnerships (PPPs) within the construction industry over the last 5 years, there are few PPPs that are financial sustainable [55] due to difficulties in balancing costs and benefits between the public and private investors [83].

Most community-scale SCP projects are built by developers in accordance with local, mandatory SCP regulations [73]. To share responsibilities for maintaining larger-scale public SCP projects is a challenge that requires detailed planning, negotiation, and timelines. It is urgent that a financial sustainable way forward is found, as sponsorship from the initial sponsorship by National Government has now been completed. At this stage, the Municipal Government in each pilot SCP city is expected to self-finance the further expansion of SCP projects during the next decade [62]. We suggest that the stakeholders (e.g., officers from local governmental institutions, communities, business owners, and residents) should engage with and participate in the local planning process to overcome identified barriers to innovation and take on the challenges of financing SCP project implementation, working with the private developers to explore jointly beneficial, collaborative strategies. For example, local arrangements could be made to promote Willingness to Pay (WTP) by beneficiaries, enable PPPs, and provide incentives (e.g., lower taxes) to private developers in return for including SCP infrastructure in their new developments [84]. These mechanisms are needed to make widening the implementation of SCP projects sustainable, especially given that the National Government wishes the SCP to cover $20 \%$ or more of urban areas in the pilot cities and recognizing that the cost of achieving this cannot be borne solely by the Municipal Governments.

\section{Improving the Current SCP Using NBS}

\subsection{Urban Development Goals}

The authorities responsible for delivering the SCP are well aware of practices abroad with respect to BMP, LID, SuDs, WSUD, LIUDD, BGI, BGCs, and, most recently, NBS [4]. However, expanding the uptake and inclusion of NBS could enrich future planning, design, and implementation of the SCP.

NBS emphasizes the optimization of urban master planning to provide ecosystem services that are sustainable given local geographical, cultural, hydroclimatic, and land-use contexts [85]. Within the paradigm of sustainable urbanization, NBS aims to develop or regenerate urban areas through conserving or renaturing urban spaces to improve public health and well-being, while making cities more liveable. In an urban context, NBS must be pragmatic, meaning that flexibility and practicality are considered to set targets that are realizable, rather than setting objectives that, though laudable, may not be achievable [86]. Setting realizable targets requires making the co-production of knowledge and ideas a priority. Hence, the roles of multiple stakeholders become central not only to conceiving what NBS looks like in any given neighbourhood but also to the co-design and co-implementation of preferred approaches, assets, and systems [87]. In China, building the trustful relationships between multiple, government, commercial, and public stakeholders necessary to support co-production is challenging because the sheer pace of development is much more intensive than in the West. Additionally, scope for co-production is limited in the pilot SCP cities by the existence of mandatory requirements, such as 
the target to reduce runoff by $70 \sim 80 \%$, that are specified in the SCP Guides. These targets are difficult to achieve in old, downtown areas but rule out alternative measures that could still increase water security, improve water and environmental quality, and decrease flood risk to levels acceptable to residents, business owners, and other beneficiaries. Learning from the theory and practice of NBS abroad by permitting greater flexibility in setting targets would allow local officials, engineers, and communities in the pilot cities to co-produce and reach realistic goals based on locally agreed SCP development paths, followed at a pace matched to local contexts, priorities, and agendas.

The advantages of implanting NBS in a coordinated programme of implementation, monitoring, and knowledge synthesis are demonstrated by the EU's Horizon 2020 programme, which has funded NBS projects in many European cities and regions all across the EU, since 2015. Experience gained in these projects demonstrates that a deep understanding of regional, catchment, and social urban spatial contexts is indeed essential for co-producing successful, local NBS strategies [88]. The EU-wide knowledge base on NBS synthesizes experience gained from successful projects. These case studies demonstrate how understanding both human physical and spatial contexts informs NBS implementation in practice. Examples of NBS approaches appropriate in different contexts include limiting the plot ratio of buildings in the city centre, renovating/replacing neglected drainage systems in older neighbourhoods, creating multi-functional buffer zones (e.g., parks, forests, riparian corridors, and reconnected floodplains) upstream of cities in lowland catchments, building recreational wetland parks within flood detention basins, and constructing/restoring littoral wetlands and tidal marshes in coastal cities [89].

More specifically, the EU Horizon 2020 Nature4Cities project was commissioned to build a common understanding of ongoing and completed NBS projects demonstrating innovative solutions in cities. The projects include URBAN GreenUP, UNaLab, proGIreg, OPERANDUM, etc. Innovative systems for water resilience using ecological approaches to cope with climate change were investigated in projects such as UNaLAB, URBAN GreenUP, and GrowGeen, while NBS addressing hydro-meteorological phenomena has been developed by the OPERANDUM project.

More specifically, the EU Horizon 2020 project Oppla created a database of multiple co-benefits generated by NBS case study projects.

The case studies database on NBS was initially developed through the Openness and OPERAs projects, and later integrated by the Oppla project as an interactive map that allows users to explore case studies in terms of natural capital, ecosystem services, and NBS (https://oppla.eu/case-studiespage). Similar concepts, such as B-GC, use evidence-based scenarios to develop multi-functional urban water management that addresses physical and socio-political factors (e.g., flood and drought risk management, social justice, and sustainable economies). B-GC also places a high value on gathering information on stakeholder preferences, perceptions, and behaviours to ascertain what drives either positive decision making or reluctance to implement innovative approaches. These social science drivers/barriers operate through government, private developers, urban planners, water engineers, residents, and Non-Governmental Organizations (NGOs) to either promote or frustrate the implementation of blue-green systems. Governance, development, and community studies have successfully addressed urban water management issues in many European cities, including, particularly, the mitigation of pluvial and surface water floods, and the discharge of urban pollutants (nutrients, heavy metals, sediments, macro- and micro-plastics, etc.) to receiving waters (e.g., urban lakes, rivers, streams, and ponds) $[90,91]$. The rich body of knowledge assembled by the EU presents an opportunity for Chinese urban planners to learn from and improve on best practice, so as to overcome the tough challenges posed by pollution, floods, and water scarcity, while avoiding mistakes that have been made elsewhere [66].

\section{2. "Green+Grey" Solutions}

To date, the pilot cities have relied on using infrastructure that is either Green (adopting the nature-based solutions and natural ecologically friendly infrastructures to deal with urban stormwater 
issues) (e.g., bio-swales, artificial wetlands, urban ponds, urban lakes, rain gardens, etc.) or Grey (usually relying on engineering approaches to deal with urban water issues) (e.g., embankments, river walls, pumping systems, land drainage, levees, etc.) to deliver SCP and urban water management practice [53]. In fact, the integration of Green and Grey assets has not yet gained popularity. NBS provides a path to combining conventional, engineered structures with more natural, ecological solutions, to build a combined solution via "Green+Grey" infrastructure [92].

If the SCP were to follow this path, this could help it improve current inadequate flood risk management design standards, leading to more resilient solutions. "Green+Grey" infrastructure includes piped drainage systems interspersed with bio-swales and SuDs ponds, residential developments with sunken rain gardens, buildings with green and blue roofs, and ecological levees and corridors that increase stormwater conveyance capacity along engineered urban drainage channels.

Such integrated "Green+Grey" infrastructure constitutes a NBS approach that can perform multiple functions because it is capable of concurrently addressing not one but several urban water issues (e.g., flood risk, pollution, urban heat island effects, water purification and reuse, biodiversity, the provision of blue-green recreational spaces, etc.) (Figure 5). For example, Hamilton City, California, and surrounding rural areas suffered nuisance flooding frequently until levees were set back to reconnect part of the natural floodplain and upgraded to increase the capacity of the wider floodway to store and convey stormwater. This "Green+Grey" solution was shown not only to be more sustainable and resilient to climate change, but also to have a higher benefit-to-cost ratio than either a "Green" solution (e.g., a flood detention basin without engineered flood control structures) or a "Grey" solution (e.g., upgrading flood embankments on their original alignments) [93].

"Green+Grey" measures and infrastructure are particularly suitable for areas where relying on GI alone cannot meet the design standards now required for urban flood risk management in Chinese cities (now usually $>$ the 1-in-100 year return period storm). The imperative to attain or exceed this standard in SCP cities is demonstrated by current experience: during summer 2020, intensive rainstorms caused severe flooding in cities across China including Chongqing, Guangzhou, Shenzhen, and Wuhan, which are all SCP pilot cities [94-98]. These storm events and urban floods reinforce the importance of merging Green and Grey approaches to adopt NBS strategies to raise flood risk management standards in SCP pilot cities [89]. In addition, "Green+Grey" approaches help to mitigate or offset the ecological negativity of "Grey" infrastructure, while reducing the economic uncertainties associated with solely "Green" solutions [99].

\subsection{Ensuring Stakeholder Engagement and Acceptance}

All urban programmes and projects are influenced by a range of stakeholders. Understanding stakeholder preferences and priorities through effective engagement is important for finding solutions that are appropriate for, supported by, and accepted by both the city's decision makers and the communities they serve [66]. Since the SCP began in 2014, the programme has mainly focused on the planning, construction, and delivery of solutions at the site-specific, project scale, based on following the relevant SCP guidance documents. The SCP has yet to include active stakeholder engagement and is far from supporting stakeholder participation [58], particularly with respect to local residents. 



Figure 5. NBS integrates the grey and green to create hybrid approaches. Closely adapted from [93].

The NBS approach prioritizes the development of appropriate methodologies for public and social engagement. In fact, NBS best practice calls for stakeholders and citizens to participate at all stages of a project, from the outset (e.g., through early consultation during planning and feasibility) to the end (e.g., through involvement in post-project monitoring, appraisal, and adaptation) [91]. NBS uses deep stakeholder engagement to facilitate knowledge transfer/exchange, the development of common narratives and shared visions, co-design, and participatory planning/modelling as a means of overcoming social barriers to innovation [100]. The potential of stakeholder participation is widely recognized, and its capacity to improve the outcomes of projects is acknowledged in a variety of disciplinary and professional contexts including the realms of politics, urban planning, architecture, civil engineering, landscape design, NGOs, and even private developers [91]. NBS recommends stakeholder analysis to provide explicit directives for project implementation. Analyses inform the understanding of the range of mixed opinions that exist within and between stakeholder groups and provide the basis for improving the project scope. Once engaged, participatory stakeholders act as "watch-dogs", monitoring project directions, developments, and progress and providing valuable 
feedback at every stage of the process [101]. Although effective stakeholder participation demands substantial time, commitment, and effort from both the project proponents and the stakeholders, the SCP should adopt stakeholder participation to enable more voices to be heard and, ultimately, to develop infrastructure that delivers multiple co-benefits that are highly valued by the intended beneficiaries.

If the SCP does buy into stakeholder participation, it should not underestimate the complexities of stakeholder ecology (e.g., issues of gender, income inequality, well-being, status, ageing, etc.). These are issues that are easy to recognize but difficult to quantify and evaluate in the context of innovative urban water management. NBS concepts, research studies, and best practices shed light on how project authorities can navigate through these complexities effectively. Successful NBS practices in European cities point the way [102]. For example, the UNaLab project developed methods for co-creating project designs with stakeholders through implementing "Living Laboratory" demonstration areas in cities hosting projects aimed at improving urban water resilience, and the proGIreg project successfully created a "Living Lab" as part of an urban water project in the Mirafiori district of Turin.

Other approaches to participation have been demonstrated in Germany. In Leipzig, an NBS project worked with private landlords to raise awareness of green issues and the need to improve local sustainability. As a result, in 2015, with the support of building owners, Leipzig was able to initiate a continuous programme of introducing green facades and green walls in Leipzig-Kletterfix. Similarly, the Ecological Festival (Umwelttage and Ökofete) has improved environmental awareness, facilitating NBS projects [23]. These types of preparatory stakeholder engagements are also undertaken in China. For example, in 2011, the Urban Agriculture Plan provided opportunities for mutual learning about urban-farmland economics, encouraging citizens to cultivate high-selling-price organic vegetables on urban farms (i.e., Urban-Rural Tourism Economy in China) for consumption within the local community. In summary, stakeholder engagement and knowledge exchange facilitate and enhance NBS opportunities in cities [61]. The proven track record of NBS in this regard illustrates how and why the SCP should embrace stakeholder participation.

\subsection{Adaptive Capacities and Strategies}

The promotion and operation of the SCP consider urban water management issues from economic, social, and environmental perspectives [47], and NBS practices suggest that further lessons could be learned regarding adaptation as an aid to planning sustainably in an uncertain future. For example, the Portofino Natural Regional Park, Liguria, Italy, implemented the "RECONECT" project to manage natural hazards in mountainous areas. The National Park and affiliated authorities implemented an NBS strategy to reduce the probability of damaging events in steep terrain. The project developed guidance on improving the stability of dangerous hillslopes, reducing upland soil and stream erosion, restoring abandoned agricultural terraces, and better maintaining hiking paths [93].

The city of Hamburg leads the European-funded CLEVER Cities project, which involves 33 cities and urban organizations distributed across Europe, South America, and China. Cities exchange knowledge and experience gained using NBS to solve urban problems, focusing on participation by local residents and businesses to collaboratively select, design, and implement NBS in districts blighted by social issues such as social inequality, high crime rates, child poverty, and unemployment [103]. Ongoing projects such as Connecting Nature, Grow Green, UNaLab, and URBAN GreenUP share the aim of using NBS to build climate and water resilience. These projects are also building an international evidence base that establishes how re-natured hydro-systems provide greater capacity for adaptation pathways and adaptive management, both of which will increase urban water resilience in an uncertain future. The findings of these on-the-ground projects demonstrate the practical efficacy, cost efficiency, and comparative advantages of a range of tested, scalable, and easy-to-promote NBS. In doing so, they are matched by other ongoing international projects such as Nature4Cities and Naturvation, which investigate how the advantages of adaptive planning and design management can be accessed through innovative approaches to governance, and the application of new tools and models for finance, business, and economic impact. 
A specific example is Newcastle-upon-Tyne, UK. The "2016 Newcastle City Strategic Surface Water Management Plan" includes greening urban streets; retaining flood water in large, multi-functional green spaces; and improving existing piped drainage systems through retrofitting surface water outfalls, bio-swales, and ponds. More ambitiously, it also promotes the creation of five "Blue/Green corridors" to convey stormwater safely through the city during extreme rainfall events [104]. These NBS are integrated systems of highly adaptive blue-green infrastructure that is tailored to local topographic and geographical conditions, while also considering each area's meteorology, hydrology, socio-economics, community preferences, and environmental issues.

Such adaptive NBS strategies could benefit Chinese cities authorized to participate in the SCP and enhance their ability to deliver multiple benefits and meet targets for hydrology (e.g., urban floods and pollution to address nutrient, metal, and microplastic discharge to freshwater bodies), land use (e.g., blue-green or green space planning), urban planning (e.g., zoning), socio-economic development (e.g., social well-being and financial development), and sustainable urban development [43].

\subsection{Using Transdisciplinary Knowledge}

Continuous knowledge-based development is a core element for the SCP [102]. The SCP needs to utilize interdisciplinary knowledge in order to achieve the maximum benefits for society, the environment, and the economy. This endeavour comes from the collaboration among engineers, planners, developers, and the public that presently takes place [60]. Although interdisciplinary urban research has been undertaken in China, further developments in integrating interdisciplinary approaches will be valuable for the SCP [105]. The "European Union Horizon 2020 Coordination and Support Action" has integrated transdisciplinary policy, case studies, application, and research data, which have been used to further develop the NBS programme at national and regional levels [101]. Another example is the "ClimateCafe" activity held globally. Young professionals worldwide in various disciplines (e.g., the urban planning, building design, hydrological, meteorological, geography, and environmental sectors) take part in the knowledge exchange events to interact and discuss climate change and NBS, providing comments and feedback, and assessing and reviewing local NBS projects [105]. Chinese authorities that are responsible for the SCP could learn from this strategy and build an open platform for interdisciplinary knowledge exchange.

\subsection{Developing an Open Assessment Platform for Future Benchmarking of SCP Practice}

Identifying and evaluating the direct and indirect impacts of SCP or NBS projects often take a long time, and trade-offs between different stakeholders are inevitable. Because of the conflicting value attributions (e.g., monetary, social, and ecological value), it is difficult to find solutions optimal for all. A clear objective and open assessment platform are required. "Nature4Cities" is the flagship project of the Horizon 2020 program in the EU, which aims to integrate multiple tools (e.g., statistics, modelling, and remote sensing) covering the economic, social, and environmental aspects of NBS at different scales [106] and conduct a comprehensive assessment of NBS. The assessment platform is open and dynamic, and the environmental assessment module plans to address the relationship between NBS and social welfare [107]. The "EPESUS City" is a platform of "Nature4Cities". It is a life-cycle technology tool that performs life-cycle assessments in a time series at the urban scale. This enables researchers to identify key indicators within a defined time frame for making decisions on urban planning strategies based on the desired performance patterns [106]. There are many dialogue platforms to promote innovation with NBS that have been funded by the European Commission (Table 4). A unified assessment platform could enable the SCP to achieve common goals regarding project costs, functions, and socio-ecological impacts, which are currently lacking. 
Table 4. EU dialogue platforms for the promotion of NBS.

\begin{tabular}{|c|c|}
\hline Project & Link to the Webpage \\
\hline $\begin{array}{c}\text { ThinkNature } \\
\text { Oppla } \\
\text { EU Smart Cities Information System (SCIS) } \\
\text { EU Climate Adaptation Platform CLIMATE-ADAPT } \\
\text { Sustainable Cities Platform }\end{array}$ & $\begin{array}{c}\text { https://www.think-nature.eu/ } \\
\text { https://www.oppla.eu/ } \\
\text { https://www.smartcitiesinfosystem.eu/ } \\
\text { https://climate-adapt.eea.europa.eu/ } \\
\text { http://www.sustainablecities.eu/ }\end{array}$ \\
\hline
\end{tabular}

The last key element is how to develop reasonable monitoring standards and assessment criteria. The effectiveness of the SCP needs to be monitored at both large (e.g., potential impact on global climate change) and small geographic scales such as at site-specific levels, particularly as SCP projects are currently restricted to construction at the community level [108]. NBS provides references for the SCP in this regard (in terms of monitoring and assessment). For example, some indicators of SCP projects should be monitored to address local conditions (e.g., socio-economic status, social well-being, hydrological patterns, soil, vegetation, and land-use changes). As a result, the authorities could collect valuable feedback to improve current projects and also develop more adaptive management practices. More strategic approaches such as the periodic random sampling of SCP sites should be undertaken in SCP projects at larger geographical scales (district or regional) over longer periods of time. It could save substantial cost and time, and also provide assessment data [41].

Setting reasonable standards of assessment remains a challenge in the SCP, as stakeholders have dissimilar perspectives. Currently, SCP performance assessment guidance and practice are still lacking $[67,109]$. We suggested that the authorities in China should design an SCP evaluation standard that includes direct indicators (e.g., to determine ecological, social, and economic effectiveness) and indirect indicators (e.g., the employment rate and sense of happiness). Raymond et al. [110] developed a framework assessing the co-benefits (and costs) of NBS in European cities, which assesses socio-cultural and socio-economic systems, biodiversity, ecosystems, climate, and physical environments. This framework also includes strategies tackling the ten most concerning urban challenges (e.g., the economy, society, environment, and climate change) [110], so as to provide specific actions to solve these challenges. The expected economic, environmental, and social impacts (e.g., direct costs and benefits) of these according actions are identified, which are addressed by the related indicators and assessment methods [93]. The advantage of this framework is that it not only focuses on the direct benefits but also highlights the various co-benefits and concerns associated with the NBS. We argue that by taking these lessons from the existing NBS frameworks, the SCP can be improved over the long term, especially for the second and third stages, as the Chinese central government plans to extend SCP construction to larger spatial scales in Chinese cities.

\section{Conclusions}

Urbanization and development in Chinese cities are continuously growing, a pattern initiated in the late 1970s. Under the latest development and regional plans in China (e.g., the Greater Bay Area Development plans in the Pearl River Delta, the Yangtze River Delta Development Plan, etc.), urban water management issues will be a tough challenge and complex. In 2014, the National Government initiated the SCP concept and practices; this strategy emerged and represented a fundamental change in urban development and water management in China by learning from successful global practices (e.g., BMPs, LID, SuDs, WSUD, LIUDD, and NBS). Currently, the NBS is a popular concept established in Europe that is rapidly diffusing with a wide range of international partnerships and applications around the world. This approach may positively influence the implementation of the SCP in Chinese cities.

In this manuscript, we are not trying to insist the SCP should be fully integrated with the NBS, as there are difficulties and challenges to implementing and interacting fully with both programs, but we review the latest development of both practices and understand the NBS provides cost-effective hybrid solutions that may enhance SCP progress by combining traditional engineering methods with natural 
elements (e.g., hybrid infrastructure and green-grey infrastructure). Moreover, NBS provides adaptive management and ecological, social, and economic benefits, which may improve the sustainability of the SCP. The innovative NBS approaches can be transformed for Chinese traditional urban water development in several ways.

For example, NBS can deal with the uncertainty and complexity of urban development, such as monitoring and evaluation by adaptive management approaches; they can ensure the involvement of multiple stakeholders, and utilize multidisciplinary and transdisciplinary knowledge for the development of common understanding of multifunctional solutions and trade-offs. Both the SCP and NBS are now "step-change" approaches, not only for addressing urban water issues but also for improving ecological and social conditions.

Several suggestions can be provided for future research as follows:

1. Develop a comprehensive self-optimizing model to identify appropriate technical measures (e.g., bio-retention systems and green roofs) in geographically diverse future Sponge Cities;

2. Establish technological approaches (e.g., AI) and networks to improve coordination across municipal departments;

3. Improve the PPP investment model and find new financial mechanisms for sustainable construction and operation;

4. Evaluate how to provide local stakeholders with greater roles in planning and development, and encourage them to participate more frequently in the SCP;

5. Develop an adaptive management approach for SCP to improve urban resilience, urban water pollution (e.g., addressing nutrient, metal, and plastic (microplastics and microbeads) issues), and water scarcity that addresses the challenges of climate change and massive urbanization in Chinese cities.

Author Contributions: Conceptualization, Y.Q., F.K.S.C., L.L. and J.G.; resources, Y.Q., F.C. and Y.S.; writing-original draft preparation, Y.Q. and F.C.; writing-review and editing, C.T., E.O., C.Q., E.C., and A.P.; supervision, M.F. All authors have read and agreed to the published version of the manuscript.

Funding: This research received no external funding.

Acknowledgments: We would like to send our gratitude for the support by the National Natural Science Foundation of China (NSFC) (41850410497, 41971040); the National Key R\&D Program of China (2019YFC1510400); the Youth Innovation Promotion Association CAS (2017074); and the British Academy Project "Developing new Blue-Green futures: multifunctional infrastructure to address water challenges", part of the British Academy Programme on Tackling the UK's International Challenges (IC3\100093).

Conflicts of Interest: The authors declare no conflict of interest.

\section{References}

1. Chan, F.; Chuah, C.J.; Ziegler, A.; Dabrowski, M.; Varis, O. Towards resilient flood risk management for Asian coastal cities: Lessons learned from Hong Kong and Singapore. J. Clean. Prod. 2018, 187, 576-589. [CrossRef]

2. Fletcher, T.D.; Shuster, W.; Hunt, W.F.; Ashley, R.; Butler, D.; Arthur, S.; Trowsdale, S.; Barraud, S.; Semadeni-Davies, A.; Bertrand-Krajewski, J.-L.; et al. SUDS, LID, BMPs, WSUD and more-The evolution and application of terminology surrounding urban drainage. Urban Water J. 2014, 12, 525-542. [CrossRef]

3. European Commission. Nature-Based Solutions. Available online: https://ec.europa.eu/research/ environment/index.cfm?pg=nbs (accessed on 18 July 2020).

4. Pontee, N.; Narayan, S.; Beck, M.W.; Hosking, A.H. Nature-based solutions: Lessons from around the world. Proc. Inst. Civ. Eng. Marit. Eng. 2016, 169, 29-36. [CrossRef]

5. Mendes, R.; Fidélis, T.; Roebeling, P.C.; Teles, F. The Institutionalization of Nature-Based Solutions-A Discourse Analysis of Emergent Literature. Resources 2020, 9, 6. [CrossRef]

6. Raymond, C.M.; Berry, P.; Breil, M.; Nita, M.R.; Kabisch, N.; Belf, M.D.; Enzi, V.; Frantzeskaki, N.; Geneletti, D.; Cardinaletti, M.; et al. An Impact Evaluation Framework to Support Planning and Evaluation of Nature-Based Solutions Projects; Centre for Ecology \& Hydrology: Wallingford, UK, 2017. 
7. Somarakis, G.; Stagakis, S.; Chrysoulakis, N. Thinknature Nature-Based Solutions Handbook; European Union: Brussels, Belgium, 2019.

8. Chan, F.K.S.; Griffiths, J.A.; Higgitt, D.; Xu, S.; Zhu, F.; Tang, Y.-T.; Xu, Y.; Thorne, C. "Sponge City" in China-A breakthrough of planning and flood risk management in the urban context. Land Use Policy 2018, 76, 772-778. [CrossRef]

9. Wang, H.; Mei, C.; Liu, J.; Shao, W. A new strategy for integrated urban water management in China: Sponge city. Sci. China Ser. E Technol. Sci. 2018, 61, 317-329. [CrossRef]

10. Xia, J.; Zhang, Y.; Xiong, L.; He, S.; Wang, L.; Yu, Z. Opportunities and challenges of the Sponge City construction related to urban water issues in China. Sci. China Earth Sci. 2017, 60, 652-658. [CrossRef]

11. Zevenbergen, C.; Fu, D.; Pathirana, A. Transitioning to Sponge Cities: Challenges and Opportunities to Address Urban Water Problems in China. Water 2018, 10, 1230. [CrossRef]

12. Ferreira, V.; Barreira, A.P.; Loures, L.; Guerreiro, A.C.; Panagopoulos, T. Stakeholders' Engagement on Nature-Based Solutions: A Systematic Literature Review. Sustainability 2020, 12, 640. [CrossRef]

13. Fish, R.; Church, A.; Willis, C.; Winter, M.; Tratalos, J.A.; Haines-Young, R.; Potschin, M. Making space for cultural ecosystem services: Insights from a study of the UK nature improvement initiative. Ecosyst. Serv. 2016, 21, 329-343. [CrossRef]

14. Busscher, T.; Brink, M.V.D.; Verweij, S. Strategies for integrating water management and spatial planning: Organising for spatial quality in the Dutch “Room for the River" program. J. Flood Risk Manag. 2018, 12, e12448. [CrossRef]

15. O’Donnell, E.; Thorne, C.; Ahilan, S.; Arthur, S.; Birkinshaw, S.; Butler, D.; Dawson, D.; Everett, G.; Fenner, R.; Glenis, V.; et al. The blue-green path to urban flood resilience. Blue Green Syst. 2019, 2, 28-45. [CrossRef]

16. Cohen-Shacham, E.; Walters, G.; Janzen, C.; Maginnis, S. Nature-Based Solutions to Address Global Societal Challenges; IUCN: Gland, Switzerland, 2016.

17. IUCN IUCN Programme 2017-2020; Switzerland. 2016. Available online: https://www.iucn.org/about/ programme-work-and-reporting/programme (accessed on 15 July 2020).

18. Turconi, L.; Faccini, F.; Marchese, A.; Paliaga, G.; Casazza, M.; Vojinovic, Z.; Luino, F. Implementation of Nature-Based Solutions for Hydro-Meteorological Risk Reduction in Small Mediterranean Catchments: The Case of Portofino Natural Regional Park, Italy. Sustainability 2020, 12, 1240. [CrossRef]

19. European Commission. Towards an EU Research and Innovation Policy Agenda for Nature-Based Solutions $\mathcal{E}$ Re-Naturing Cities; Publications Office of the European Union: Brussels, Belgium, 2015.

20. Debele, S.E.; Kumar, P.; Sahani, J.; Marti-Cardona, B.; Mickovski, S.B.; Leo, L.S.; Porcù, F.; Bertini, F.; Montesi, D.; Vojinovic, Z.; et al. Nature-based solutions for hydro-meteorological hazards: Revised concepts, classification schemes and databases. Environ. Res. 2019, 179, 108799. [CrossRef] [PubMed]

21. Faivre, N.; Fritz, M.; Freitas, T.; De Boissezon, B.; Vandewoestijne, S. Nature-Based Solutions in the EU: Innovating with nature to address social, economic and environmental challenges. Environ. Res. 2017, 159, 509-518. [CrossRef] [PubMed]

22. UN. The United Nations World Water Development Report 2018; The United Nations Educational, Scientific and Cultural Organization: Paris, France, 2018.

23. Dushkova, D.; Haase, D. Not Simply Green: Nature-Based Solutions as a Concept and Practical Approach for Sustainability Studies and Planning Agendas in Cities. Land 2020, 9, 19. [CrossRef]

24. Di Matteo, M.; Dandy, G.C.; Maier, H.R. A multi-stakeholder portfolio optimization framework applied to stormwater best management practice (BMP) selection. Environ. Model. Softw. 2017, 97, 16-31. [CrossRef]

25. United States Environmental Protection Agency Best Management Practices (BMPs) Siting Tool. Available online: https://www.epa.gov/water-research/best-management-practices-bmps-siting-tool (accessed on 5 August 2020).

26. Ballard, W.; Wilson, S.; Udale-Clarke, H.; Illman, S.; Scott, T.; Ashley, R.; Kellagher, R. The SuDS Manual; CIRIA: London, UK, 2015.

27. Gimenez-Maranges, M.; Breuste, J.; Hof, A. Sustainable Drainage Systems for transitioning to sustainable urban flood management in the European Union: A review. J. Clean. Prod. 2020, 255, 120191. [CrossRef]

28. Matos, C.; Sá, A.B.; Bentes, I.; Pereira, S.; Bento, R. An approach to the implementation of Low Impact Development measures towards an EcoCampus classification. J. Environ. Manag. 2019, 232, 654-659. [CrossRef] 
29. Dietz, M.E. Low Impact Development Practices: A Review of Current Research and Recommendations for Future Directions. Water Air Soil Pollut. 2007, 186, 351-363. [CrossRef]

30. Cook, S.; Van Roon, M.; Ehrenfried, L.; Lagro, J.; Yu, Q. WSUD “Best in Class”—Case Studies from Australia, New Zealand, United States, Europe, and Asia. In Approaches to Water Sensitive Urban Design; Elsevier: Amsterdam, The Netherlands, 2019; pp. 561-585.

31. Wong, T.H.F. Water sensitive urban design-The journey thus far. Australas. J. Water Resour. 2006, 10, $213-222$. [CrossRef]

32. Beecham, S.; Razzaghmanesh, M.; Bustami, R.; Ward, J.D. The Role of Green Roofs and Living Walls as WSUD Approaches in a Dry Climate. In Approaches to Water Sensitive Urban Design; Elsevier: Amsterdam, The Netherlands, 2019; pp. 409-430.

33. Van Roon, M.R. Water sensitive residential developments: Application of LIUDD principles and methods in the Netherlands, Australia and New Zealand. Urban Water J. 2011, 8, 325-335. [CrossRef]

34. Van Roon, M. Low impact urban design and development: Catchment-based structure planning to optimise ecological outcomes. Urban Water J. 2011, 8, 293-308. [CrossRef]

35. Venkataramanan, V.; Lopez, D.; McCuskey, D.J.; Kiefus, D.; McDonald, R.I.; Miller, W.M.; Packman, A.I.; Young, S.L. Knowledge, attitudes, intentions, and behavior related to green infrastructure for flood management: A systematic literature review. Sci. Total. Environ. 2020, 720, 137606. [CrossRef] [PubMed]

36. Goh, X.P.; Radhakrishnan, M.; Zevenbergen, C.; Pathirana, A. Effectiveness of Runoff Control Legislation and Active, Beautiful, Clean (ABC) Waters Design Features in Singapore. Water 2017, 9, 627. [CrossRef]

37. O'Donnell, E.C.; Thorne, C.; Yeakley, J.A. Managing urban flood risk in Blue-Green cities: The Clean Water for All initiative. J. Flood Risk Manag. 2018, 12, e12513. [CrossRef]

38. O'Donnell, E.C.; Lamond, J.E.; Thorne, C.R. Recognising barriers to implementation of Blue-Green Infrastructure: A Newcastle case study. Urban Water J. 2017, 14, 964-971. [CrossRef]

39. Chan, F.K.S.; Olalekan, A.A.; Cho, N.N.; Gordon, M.; Adrian, T.M. Coastal Flood-Risk Management Practice in Tai 0, a Town in Hong Kong. Environ. Pract. 2013, 9, 201-219. [CrossRef]

40. Nguyen, T.T.; Ngo, H.H.; Guo, W.S.; Wang, X.C.; Ren, N.; Li, G.; Ding, J.; Liang, H. Implementation of a specific urban water management-Sponge City. Sci. Total. Environ. 2019, 652, 147-162. [CrossRef]

41. Shao, W.; Zhang, H.; Liu, J.; Yang, G.; Chen, X.; Yang, Z.; Huang, H. Data Integration and its Application in the Sponge City Construction of China. Procedia Eng. 2016, 154, 779-786. [CrossRef]

42. Yanan, J.; Faith, K.S.C.; Joseph, H.; Yaqian, Z.; Dabo, G. China's Water Management Challenges and Solutions. Environ. Eng. Manag. J. 2013, 12, 1311-1321.

43. He, B.-J.; Zhu, J.; Zhao, D.-X.; Gou, Z.-H.; Qi, J.-D.; Wang, J. Co-Benefits approach: Opportunities for implementing sponge city and urban heat island mitigation. Land Use Policy 2019, 86, 147-157. [CrossRef]

44. Liang, C.; Li, D.; Yuan, Z.; Liao, Y.; Nie, X.; Huang, B.; Wu, X.; Xie, Z. Assessing urban flood and drought risks under climate change, China. Hydrol. Process. 2019, 33, 1349-1361. [CrossRef]

45. China Daily. Over 20m Chinese People Affected by Floods in July. Available online: https://global.chinadaily. com.cn/a/202007/17/WS5f11004ea31083481725a1b4.html (accessed on 17 July 2020).

46. Shang, Y.; Lu, S.; Li, X.; Sun, G.; Shang, L.; Shi, H.; Lei, X.; Ye, Y.; Sang, X.; Wang, H. Drivers of industrial water use during 2003-2012 in Tianjin, China: A structural decomposition analysis. J. Clean. Prod. 2017, 140, 1136-1147. [CrossRef]

47. Li, B.; Dong, S.; Huang, Y.; Wang, G.Q. Development of a Heterogeneity Analysis Framework for Collaborative Sponge City Management. Water 2019, 11, 1995. [CrossRef]

48. Chang, H.; Su, Q. Research on constructing sponge city indicator and decision evaluation model with fuzzy multiple criteria method. Water Environ. Res. 2020, 5, 1-12. [CrossRef]

49. Lancia, M.; Zheng, C.; He, X.; Lerner, D.N.; Andrews, C.; Tian, Y. Hydrogeological constraints and opportunities for "Sponge City" development: Shenzhen, southern China. J. Hydrol. Reg. Stud. 2020, 28, 100679. [CrossRef]

50. Nguyen, T.T.; Ngo, H.H.; Guo, W.S.; Wang, X.C. A new model framework for sponge city implementation: Emerging challenges and future developments. J. Environ. Manag. 2020, 253, 109689. [CrossRef]

51. Jia, H.; Wang, Z.; Zhen, X.; Clar, M.; Yu, S.L. China's sponge city construction: A discussion on technical approaches. Front. Environ. Sci. Eng. 2017, 11, 18. [CrossRef]

52. Li, H.; Ding, L.; Ren, M.; Li, C.; Wang, H. Sponge City Construction in China: A Survey of the Challenges and Opportunities. Water 2017, 9, 594. [CrossRef] 
53. Xiang, C.; Liu, J.; Shao, W.; Mei, C.; Zhou, J. Sponge city construction in China: Policy and implementation experiences. Hydrol. Res. 2018, 21, 19-37. [CrossRef]

54. Wang, K.; Wang, L.; Wei, Y.-M.; Ye, M. Beijing storm of July 21, 2012: Observations and reflections. Nat. Hazards 2013, 67, 969-974. [CrossRef]

55. Zhang, L.; Sun, X.; Xue, H. Identifying critical risks in Sponge City PPP projects using DEMATEL method: A case study of China. J. Clean. Prod. 2019, 226, 949-958. [CrossRef]

56. Tang, Y.; Chan, F.K.S.; O'Donnell, E.; Griffiths, J.; Lau, L.; Higgitt, D.; Thorne, C.; Thorne, T. Aligning ancient and modern approaches to sustainable urban water management in China: Ningbo as a "Blue-Green City" in the "Sponge City" campaign. J. Flood Risk Manag. 2018, 11, e12451. [CrossRef]

57. Shen, W.; Liu, Y.; Wu, M.; Zhang, D.; Du, X.; Zhao, D.; Xu, G.; Zhang, B.; Xiong, X. Ecological carbonated steel slag pervious concrete prepared as a key material of sponge city. J. Clean. Prod. 2020, 256, 120244. [CrossRef]

58. Wang, Y.; Sun, M.; Song, B. Public perceptions of and willingness to pay for sponge city initiatives in China. Resour. Conserv. Recycl. 2017, 122, 11-20. [CrossRef]

59. Peng, J.; Ouyang, J.; Yu, L. The model of low impact development of a sponge airport: A case study of Beijing Daxing International Airport. J. Water Clim. Chang. 2020, 11, 1-11. [CrossRef]

60. Griffiths, J.A.; Chan, F.K.S.; Shao, M.; Zhu, F.; Higgitt, D.L. Interpretation and application of Sponge City guidelines in China. Philos. Trans. R. Soc. A Math. Phys. Eng. Sci. 2020, 378, 20190222. [CrossRef]

61. Lashford, C.; Rubinato, M.; Cai, Y.; Hou, J.; Abolfathi, S.; Coupe, S.; Charlesworth, S.; Tait, S. SuDS \& Sponge Cities: A Comparative Analysis of the Implementation of Pluvial Flood Management in the UK and China. Sustainability 2019, 11, 213.

62. Wang, Y.; Liu, X.; Huang, M.; Zuo, J.; Rameezdeen, R. Received vs. given: Willingness to pay for sponge city program from a perceived value perspective. J. Clean. Prod. 2020, 256, 120479. [CrossRef]

63. Chen, Y.; Chen, H. The Collective Strategies of Key Stakeholders in Sponge City Construction: A Tripartite Game Analysis of Governments, Developers, and Consumers. Water 2020, 12, 1087. [CrossRef]

64. Liang, X.; Liang, Y.; Chen, C.; Van Dijk, M.P. Implementing Water Policies in China: A Policy Cycle Analysis of the Sponge City Program Using Two Case Studies. Sustainability 2020, 12, 5261. [CrossRef]

65. Yawen, W.; Jun, L.; Haowen, X.; Guangyuan, Y.; Hong, Z.; Yichen, Y. Towards government mechanisms of sponge city construction in China: Insights from developed countries. Hydrol. Res. 2020, 22, 574-590. [CrossRef]

66. Li, N.; Qin, C.; Du, P. Multicriteria Decision Analysis Applied to Sponge City Construction in China: A Case Study. Integr. Environ. Assess. Manag. 2019, 15, 703-713. [CrossRef]

67. Li, Q.; Wang, F.; Yu, Y.; Huang, Z.; Li, M.; Guan, Y. Comprehensive performance evaluation of LID practices for the sponge city construction: A case study in Guangxi, China. J. Environ. Manag. 2019, 231, 10-20. [CrossRef]

68. Su, D.; Zhang, Q.; Ngo, H.; Dzakpasu, M.; Guo, W.; Wang, X.C. Development of a water cycle management approach to Sponge City construction in Xi'an, China. Sci. Total. Environ. 2019, 685, 490-496. [CrossRef]

69. Wendling, L.; Huovila, A.; Castell-Rüdenhausen, Z.M.; Hukkalainen, M.; Airaksinen, M. Benchmarking Nature-Based Solution and Smart City Assessment Schemes Against the Sustainable Development Goal Indicator Framework. Front. Environ. Sci. 2018, 6, 6. [CrossRef]

70. Gulsrud, N.M.; Hertzog, K.; Shears, I. Innovative urban forestry governance in Melbourne? Investigating "green placemaking" as a nature-based solution. Environ. Res. 2018, 161, 158-167. [CrossRef]

71. Han, H.; Hyun, S.S. Green indoor and outdoor environment as nature-based solution and its role in increasing customer/employee mental health, well-being, and loyalty. Bus. Strat. Environ. 2018, 28, 629-641. [CrossRef]

72. Zevenbergen, C.; Veerbeek, W.; Gersonius, B.; Van Herk, S. Challenges in urban flood management: Travelling across spatial and temporal scales. J. Flood Risk Manag. 2008, 1, 81-88. [CrossRef]

73. Zhou, J.; Liu, J.; Shao, W.; Yu, Y.; Zhang, K.; Wang, Y.; Mei, C. Effective Evaluation of Infiltration and Storage Measures in Sponge City Construction: A Case Study of Fenghuang City. Water 2018, 10, 937. [CrossRef]

74. Yuan, Y.; Xu, Y.-S.; Arulrajah, A. Sustainable Measures for Mitigation of Flooding Hazards: A Case Study in Shanghai, China. Water 2017, 9, 310. [CrossRef]

75. Qiao, X.-J.; Liao, K.-H.; Randrup, T.B. Sustainable stormwater management: A qualitative case study of the Sponge Cities initiative in China. Sustain. Cities Soc. 2020, 53, 101963. [CrossRef]

76. Li, J.; Mu, C.; Deng, C.; Ma, M. Hydrologic-environmental effects of sponge city under different spatial scales. J. Water Reuse Desalin. 2019, 10, 45-56. [CrossRef] 
77. Wang, C.; Hou, J.; Miller, D.; Brown, I.; Jiang, Y. Flood risk management in sponge cities: The role of integrated simulation and 3D visualization. Int. J. Disaster Risk Reduct. 2019, 39, 101139. [CrossRef]

78. Hou, J.; Mao, H.; Li, J.; Sun, S. Spatial simulation of the ecological processes of stormwater for sponge cities. J. Environ. Manag. 2019, 232, 574-583. [CrossRef]

79. Zaji, A.H.; Bonakdari, H.; Gharabaghi, B. Developing an AI-based method for river discharge forecasting using satellite signals. Theor. Appl. Clim. 2019, 138, 347-362. [CrossRef]

80. Sun, W.; Bocchini, P.; Davison, B.D. Applications of artificial intelligence for disaster management. Nat. Hazards 2020, 103, 2631-2689. [CrossRef]

81. Fotovatikhah, F.; Herrera, M.; Shamshirband, S.; Chau, K.; Ardabili, S.F.; Piran, J. Survey of computational intelligence as basis to big flood management: Challenges, research directions and future work. Eng. Appl. Comput. Fluid Mech. 2018, 12, 411-437. [CrossRef]

82. Ren, N.; Wang, Q.; Wang, Q.; Huang, H.; Wang, X. Upgrading to urban water system 3.0 through sponge city construction. Front. Environ. Sci. Eng. 2017, 11, 4. [CrossRef]

83. Zhang, S.; Zevenbergen, C.; Rabe, P.; Jiang, Y. The Influences of Sponge City on Property Values in Wuhan, China. Water 2018, 10, 766. [CrossRef]

84. Li, L.; Collins, A.M.; Cheshmehzangi, A.; Chan, F.K.S. Identifying enablers and barriers to the implementation of the Green Infrastructure for urban flood management: A comparative analysis of the UK and China. Urban For. Urban Green. 2020, 54, 126770. [CrossRef]

85. Vujcic, M.; Tomicevic-Dubljevic, J.; Grbic, M.; Lecic-Tosevski, D.; Vukovic, O.; Toskovic, O. Nature based solution for improving mental health and well-being in urban areas. Environ. Res. 2017, 158, 385-392. [CrossRef] [PubMed]

86. Liquete, C.; Udias, A.; Conte, G.; Grizzetti, B.; Masi, F. Integrated valuation of a nature-based solution for water pollution control. Highlighting hidden benefits. Ecosyst. Serv. 2016, 22, 392-401. [CrossRef]

87. Dennis, M.; James, P. User participation in urban green commons: Exploring the links between access, voluntarism, biodiversity and well being. Urban For. Urban Green. 2016, 15, 22-31. [CrossRef]

88. Artmann, M.; Sartison, K. The Role of Urban Agriculture as a Nature-Based Solution: A Review for Developing a Systemic Assessment Framework. Sustainability 2018, 10, 1937. [CrossRef]

89. Roggema, R. Nature-Driven Urbanism; Springer: Cham, Switzerland, 2019; pp. 1-8.

90. Krivtsov, V.; Arthur, S.; Buckman, J.; Kraiphet, A.; Needham, T.; Gu, W.; Gogoi, P.; Thorne, C. Characterisation of suspended and sedimented particulate matter in blue-green infrastructure ponds. Blue Green Syst. 2020, 2, 214-236. [CrossRef]

91. O'donnell, E.; Lamond, J.; Thorne, C. Learning and Action Alliance framework to facilitate stakeholder collaboration and social learning in urban flood risk management. Environ. Sci. Policy 2018, 80, 1-8. [CrossRef]

92. Frantzeskaki, N.; McPhearson, T.; Collier, M.J.; Kendal, D.; Bulkeley, H.; Dumitru, A.; Walsh, C.; Noble, K.; Van Wyk, E.; Ordóñez, C.; et al. Nature-Based Solutions for Urban Climate Change Adaptation: Linking Science, Policy, and Practice Communities for Evidence-Based Decision-Making. BioScience 2019, 69, 455-466. [CrossRef]

93. Kabisch, N.; Korn, H.; Stadler, J.; Bonn, A. Nature-Based Solutions to Climate Change Adaptation in Urban Areas_Linkages between Science, Policy and Practice; Springer: Cham, Switzerland, 2017; p. 96.

94. China Daily. Flood Hits Southwest China's Chongqing. Available online: http://www.chinadaily.com.cn/a/ 202007/18/WS5f12bb3fa31083481725a752.html (accessed on 18 July 2020).

95. China Daily. Xi Calls for Stronger Flood Measures. Available online: http://www.chinadaily.com.cn/a/202007/ 18/WS5f122a16a31083481725a61b.html (accessed on 18 July 2020).

96. China Daily. 20,000 Relocated After Rainstorms Hit China's Guangdong. Available online: https://www. chinadaily.com.cn/a/202006/09/WS5edf4e39a310834817251e4e.html (accessed on 15 June 2020).

97. China Daily. Riverside Wuhan Battling Flood After Overcoming COVID-19 Outbreak. Available online: https://www.chinadaily.com.cn/a/202007/15/WS5f0e3d3ba310834817259736.html (accessed on 15 July 2020).

98. The New York Times. Severe Floods in China Leave Over 106 Dead or Missing. Available online: https://www.nytimes.com/2020/07/03/world/asia/china-floods-rain.html (accessed on 19 July 2020).

99. Lim, H.S.; Lu, X. Sustainable urban stormwater management in the tropics: An evaluation of Singapore's ABC Waters Program. J. Hydrol. 2016, 538, 842-862. [CrossRef] 
100. Frantzeskaki, N. Seven lessons for planning nature-based solutions in cities. Environ. Sci. Policy 2019, 93, 101-111. [CrossRef]

101. Oral, H.V.; Carvalho, P.; Gajewska, M.; Ursino, N.; Masi, F.; Van Hullebusch, E.D.; Kazak, J.K.; Exposito, A.; Cipolletta, G.; Andersen, T.R.; et al. A review of nature-based solutions for urban water management in European circular cities: A critical assessment based on case studies and literature. Blue Green Syst. 2020, 2, 112-136. [CrossRef]

102. Calliari, E.; Staccione, A.; Mysiak, J. An assessment framework for climate-proof nature-based solutions. Sci. Total. Environ. 2019, 656, 691-700. [CrossRef] [PubMed]

103. ThinkNature. Platform for NBS. Available online: https://www.think-nature.eu/ (accessed on 15 July 2020).

104. Newcastle City Strategic Surface Water Management Plan; Newcastle City Council: Newcastle, UK, 2016.

105. Boogaard, F.; Venvik, G.; De Lima, R.L.P.; Cassanti, A.C.; Roest, A.H.; Zuurman, A. ClimateCafé: An Interdisciplinary Educational Tool for Sustainable Climate Adaptation and Lessons Learned. Sustainability 2020, 12, 3694. [CrossRef]

106. Ramusino, L.C.; Cortese, M.; Lennard, Z. Re-Naturing the City: Nature4Cities Project to Elevate the Concept of Nature-Based Solutions. Proceedings 2017, 1, 696. [CrossRef]

107. Van den Bosch, M.; Ode Sang, A. Urban natural environments as nature-based solutions for improved public health-A systematic review of reviews. Environ. Res. 2017, 158, 373-384. [CrossRef] [PubMed]

108. Hutchins, M.G.; McGrane, S.J.; Miller, J.D.; Hagen-Zanker, A.; Kjeldsen, T.R.; Dadson, S.; Rowland, C. Integrated modeling in urban hydrology: Reviewing the role of monitoring technology in overcoming the issue of 'big data' requirements. Wiley Interdiscip. Rev. Water 2016, 4, e1177. [CrossRef]

109. Hu, M.; Zhang, X.; Li, Y.; Yang, H.; Tanaka, K. Flood mitigation performance of low impact development technologies under different storms for retrofitting an urbanized area. J. Clean. Prod. 2019, 222, 373-380. [CrossRef]

110. Raymond, C.M.; Frantzeskaki, N.; Kabisch, N.; Berry, P.; Breil, M.; Nita, M.R.; Geneletti, D.; Calfapietra, C. A framework for assessing and implementing the co-benefits of nature-based solutions in urban areas. Environ. Sci. Policy 2017, 77, 15-24. [CrossRef]

(C) 2020 by the authors. Licensee MDPI, Basel, Switzerland. This article is an open access article distributed under the terms and conditions of the Creative Commons Attribution (CC BY) license (http://creativecommons.org/licenses/by/4.0/). 